\title{
Nonlinear Dynamic Analysis of the Aircraft Impact to the NPP Structures
}

Juraj Králik ${ }^{1}$, Juraj Králik jr. ${ }^{2}$

${ }^{1}$ Faculty of Civil Engineering, STU in Bratislava, Radlinského 11, 81005 Bratislava, Slovakia, e-mail: juraj.kralik@stuba.sk

${ }^{2}$ Faculty of Architecture, STU in Bratislava, Námestie Slobody 19, 81245 Bratislava, Slovakia, e-mail: kralik@fa.stuba.sk

This paper presents the nonlinear analysis of the reinforced concrete buildings of nuclear power plant under the aircraft attack. The response from the nonlinear analysis was considered taken the deterministic calculation procedures. The dynamic load is defined in time on base of the airplane impact simulations considering the real stiffness, masses, direc-tion and velocity of the flight. The dynamic response is calculated in the system ANSYS using the transient nonlinear analysis solution method. The damage of the concrete wall is evaluated in accordance with the standard NDRC consid-ering the spalling, scabbing and perforation effects. The simple and detailed calculations of the wall damage are compared.

Keywords: Nonlinear, Dynamic, Aircraft, NPP, ANSYS

\section{Acknowledgement}

The project was performed with the financial support of the Grant Agency of the Slovak Republic (VEGA 1/0265/16).

\section{References}

[1] ADAMÍK, V. (2013). Aircraft load function from the impact of JAS 39 GRIPEN, LEAR JET 25 and AIRBUS A 320, Research report No. 5090, Pardubice - April.

[2] BANGASH, M. Y. H. BANGASH, T. (2006) Explosion-Resistant Buildings. Design, Analysis, and Case Studies, Springer Berlin Heidelberg New York.

[3] BAŽANT, Z. P. PANG, S. D. VOŘECHOVSKÝ, M. AND NOVÁK. D. (2007). Energetic-statistical size effect simulated by SFEM with stratified sampling and crack band model. International Journal for Numerical Methods in Engineering (Wiley), 71(11):1297-1320, Rep. Dept. of Civil Eng., Northwestern University, Evanston, Illinois.

[4] BEZECNÝ,J. ŠTRBA, J. DUBEC, A. (2015). Material analysis of Projectile Hard Core, Manufacturing Technology Journal, p. 762-765, V.15, No. 5, M2015138.

[5] DOE STANDARD. (2006). Accident Analysis for Aircraft Crash into Hazardous Facilities, Appendix C, DOE STD3014 - 2006, October 1996, Riaffirmation May 2006, USA Department of Energy, Washington, DC 20585.

[6] ERIN, (2003) Resistance of Nuclear Power Plant Structures Housing Nuclear Fuel to Aircraft Crash Impact, (Safeguards Material), Final Report by ABS Consulting, Anatech, and ERIN Engineering, Electric Power Research Institute, Paolo Alto, CA, February.

[7] IAEA Safety Standards, (2006) Advanced Nuclear Plant Design Options to Scope with External Events, IAEATECDOC-1487, Vienna, February.

[8] KOHNKE, P. (2008). ANSYS, Theory, SAS IP Inc. Canonsburg.

[9] KRÁLIK, J. (2009). Safety and Reliability of Nuclear Power Buildings in Slovakia. Earthquake-Impact-Explosion. Published by STU Bratislava, 307pp.

[10] KRÁLIK, J. (2014). Safety of Nuclear Power Plants under the Aircraft Attack, In: Applied Mechanics and Materials Vols. 617 pp 76-80, (C) Trans Tech Publications, Switzerland, DOI:10.4028/www.scientific.net/ AMM.617.76, ISSN 1662-7482.

[11] MONOTTI, M. N. (2004). Reinforced Concrete Slabs - Compatibility Limit Design, Ph.D. thesis, Swiss Federal Institute of Technology Zurich.

[12] NEI 07-13, (2011). Revision 8P, Methodology for Performing Aircraft Impact Assessments for New Plant Designs, ERIN, Palo Alto, CA, April.

[13] NEA/CNRA/.R (2011). 12. Proceedings of the Forum on the Fukushima Accident: Insights and Approaches, JT03312480, Nov. 2011, OECD. 
[14] NĚMEC, I. SYCHROVÁ, Š. ŠEVČÍK, I. KABELÁČ, J. (2012). Study of a Nuclear Power Plant Containment Damage Caused by Impact of a Plane, In: International Refereed Journal of Engineering and Science (IRJES), ISSN (Online) 2319-183X, (Print) 2319-1821, Vol. 1, Issue 4. December, 2012, pp. 48-53 www.irjes.com.

[15] RIERA, J. D. (1968). On the Stress Analysis of Structures Subjected to Aircraft Crash on Building Structures. Nuclear Engineering and Design. Vol. 8. pp. 415-426.

[16] RIERA, J. D. (1982). An approach to evaluate the Design Load Time History for Normal Engine Impact taking into account the crash-Velocity Distribution, Nuclear Engineering and Design, 71, pp. 311-316.

[17] SIEFERT A., HENKEL F. O. (2011). Nonlinear Analysis of Commercial Aircraft Impact on A Reactor Building - Comparison Between Integral And Decoupled Crash Simulation, - Transactions SMiRT 21, Div-III: Paper ID\# 144.

[18] SUGANO,T. (1993). Local Damage to Reinforced Concrete Structures Caused by Aircraft Engine Missiles: Part 2, Evaluation of Test Results, Nuclear Engineering and Design, Vol. 140, pp. 407-423.

[19] SUCHARDA, O., BROŽOVSKÝ, J., MIKOLÁŠEK, D. (2014). Numerical Modelling and Bearing Capacity of Reinforced Concrete Beams. Key Engineering Materials, pp. 281-284.

[20] ŽMINDÁK, M., PELAGIČ, Z., SOUKUP, J. (2015). Analysis of Fibre Orientation Influence to Dynamic Properties of Composite Structures, Manufacturing Technology Journal, p.490-494, V.15, No.3, M201584.

Copyright (C) 2016. Published by Manufacturing Technology. All rights reserved. 